\title{
Flourishing or floundering: Factors Contributing to CLIL Primary Teachers' Wellbeing in Austria
}

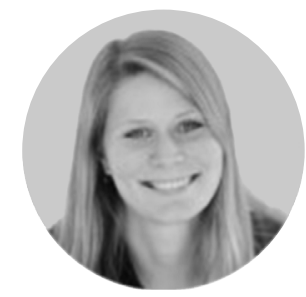

MARIE-THERES GRUBER

KPH GRAZ

marie.gruber@kphgraz.at

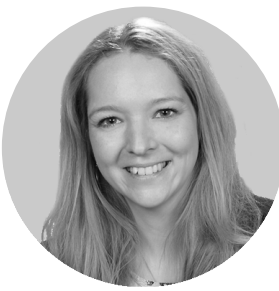

ANITA LÄMMERER

UNIVERSITY OF GRAZ

anita.laemmerer@uni-graz.at

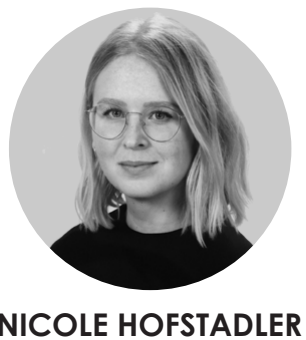

UNIVERSITY OF GRAZ

nicole.hofstadler@bildung.gv.at

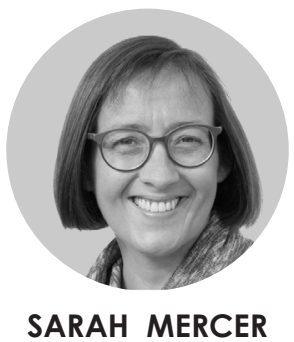

UNIVERSITY OF GRAZ

sarah.mercer@uni-graz.at
$\mathrm{C}$ LIL approaches to teaching are part of the general increase in plurilingual approaches to education. Recent work on CLIL in primary education has shown how demanding this can be for teachers. To better understand the nature of these challenges and their potential impact on teacher wellbeing, this study investigated the situation of CLIL primary teachers in Austria. Data were collected via in-depth interviews and coded in an inductive manner using QCAmap software. The analysis of the data revealed that despite considerable individual variation in terms of how CLIL was put into practice, all the wellbeing of all of the teachers' in this study appeared to be threatened by a lack of teaching material, negative public perceptions of teachers generally, low societal appreciation of primary teachers specifically, and language-related challenges in teaching CLIL. In contrast, the teachers' relationships with their students and their conviction in the CLIL approach seemed to contribute positively to their sense of wellbeing in their professional roles. We conclude with some considerations for practice to ensure all primary CLIL teachers flourish in their professional roles.

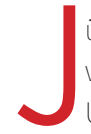
ungst entstandene Forschung zu CLIL im Primarbereich hat gezeigt wie herausfordernd diese Arbeit für Lehrpersonen sein kann. Um die Natur dieser Herausforderungen und ihre potentiellen Auswirkungen auf das Wohlbefinden der Lehrperson besser zu verstehen, untersucht diese Studie die Situation von CLIL Lehrpersonen im Primarbereich in Österreich. Die Daten wurden mit Interviews erhoben, welche in induktiver Herangehensweise mit der QCAmap Software analysiert wurden. Die Datenanalyse ergab, dass trotz individueller Variation in der Umsetzung von CLIL, das Wohlbefinden der Lehrpersonen vom Mangel an Unterrichtsmaterialien, negativer öffentlicher Wahrnehmung und geringer gesellschaftlicher Wertschätzung sowie zusätzlichen sprachspezifischen Hürden gefährdet wird. Im Gegensatz dazu begünstigen die Schülerlnnen-Lehrerlnnen-Beziehung sowie die Überzeugung vom CLIL Unterrichtsansatz das subjektive Wohlbefinden.

\section{KEYWORDS:}

CLIL; Austria; wellbeing; primary teachers.

\section{SCHLÜSSELWÖRTER:}

CLIL; Österreich; Zufriedenheit; Volksschullehrerlnnen. 


\section{Introduction}

$\mathrm{T}$ eaching Content and Language Integrated Learning (CLIL) can be an enjoyable but demanding endeavour (Vázquez \& Ellison, 2018). At the primary level in Austria, teachers are largely responsible themselves for planning, preparing and teaching CLIL, with little overall institutional or national coordination. Despite the impact of teachers on the practice of CLIL, little empirical attention has so far been given to them both as a population generally and specifically in terms of how they respond to their roles as CLIL teachers. This study aimed to focus on CLIL teachers at primary level to better understand their unique situation and working conditions, concentrating on what they enjoy but also what they find demanding about this role. CLIL in this setting refers to teaching and learning content in the foreign language English. In particular, we focus on the subjective wellbeing (SWB) of such teachers, given the central role that wellbeing can play in teacher effectiveness and ultimate learner achievement (Barber \& Mourshed, 2007; Caprara, Barbaranelli, Steca, \& Malone, 2006).

\section{Literature Review}

\subsection{CLIL in primary education}

$\mathrm{R}$ ecent years have witnessed an expansion of CLIL across all educational levels (Dafouz \& Guerrini, 2009) including primary schools (e.g., Burmeister \& Pastemak, 2007; Infante, Benvenuto, \& Lastrucci, 2008; Massler, 2012) secondary schools (e.g., Codó \& Patiño-Santos, 2018; Dalton-Puffer, 2007; Dalton-Puffer \& Smit, 2007) and tertiary-level institutions (e.g., Aguilar \& Rodríguez, 2012; Vázquez \& Gaustad, 2013). The increase of CLIL in primary education throughout Europe stems from the idea that foreign language exposure at a young age encourages positive attitudes towards language learning (Pladevall-Ballester, 2018), and the theory that the earlier the better (Read, 2005; Rixon, 2011, 2013; Singleton, 2002, 2003). On a policy level, CLIL is strongly supported by the European Union where one of their aims is to develop plurilingual competences among their citizens (Alarcao, Andrade, Araújo, Melo-Pfeifer \& Santos, 2009; Krey, 2009; Sudhoff, 2010) with CLIL having been identified as a suitable method for supporting cultural, religious and linguistic diversity (European Parliament, 2001).

In Austria, the most recent primary school curriculum reform in 2003 suggests that the process of teaching a foreign language should be integrated into all of the general subjects in primary school classrooms. However, "language and content integration stipulated by the curriculum is rarely found $[\ldots]$ " in general (Dalton-Puffer, Faistauer, \& Vetter, 2011, p. 193). Possible reasons for this include the fact that primary teachers need to put in additional effort into preparing specific materials (e.g., Buchholz, 2007; Gruber, 2017; Millonig, 2015), and also often need to acquire additional skills and competences in areas such as foreign language didactics, CLIL methodology, target language competences, and subject competences. In primary education, teachers often receive no formalised training to prepare them for such a role (Buchholz, 2007; Millonig, 2015). This precarious situation has the potential to negatively affect their professional wellbeing and confidence as educators. This study set out to explore whether this was indeed the case or whether teachers were in fact blossoming in these challenging but potentially also rewarding new roles.

\subsection{Teacher wellbeing}

Teaching is reported to be one of the most stressful professions (Borman \& Dowling, 2008; Byrne, 1999; Lovewell, 2012) with high rates of burnout (Byrne, 1999; Maslach, Schaufeli, \& Leiter, 2001). Perhaps unsurprisingly, this has also led to worrying attrition rates, especially among teachers at the early stages of their careers who face realities quite different to their expectations and hopes (Farrell, 2016; Johnson, Down, Le Cornu, Peters, Sullivan, Pearce, \& Hunter, 2016). Teaching is said to be "a profession in crisis" (Hiver \& Dörnyei, 2015, p. 2).

Subjective Wellbeing (SWB) refers to a person's perception of their lives and experiences, and includes "both cognitive judgments and affective reactions" (Diener, 1984, p. 542). It is typically understood as being comprised of satisfaction, a lack of negative emotions and a higher proportion of positive emotions (Diener, 1984; Diener, Oishi, \& Lucas, 2003). While aspects of wellbeing have been studied in a range of diverse contexts for over three decades (Pavot, Diener, Oishi, \& Tay, 2018), empirical inquiry into the wellbeing of teachers has a much shorter history. However, studies have shown how important it is for teachers to flourish in their professional roles. For example, a positive correlation between teacher's wellbeing and their teaching effectiveness has been found in several studies (Barber \& Mourshed, 2007; Caprara, Barbaranelli, Steca, \& Malone, 2006). It has also been found to connect positively with student achievements (Briner \& Dewberry, 2007; Caprara et al., 2006) meaning that teacher wellbeing is not only good for the teachers but also for their learners. In the field of language education specifically, language teacher wellbeing may also be threatened by a number of additional factors such as language anxiety due to (perceived) lack of proficiency and training (Talbot \& Mercer, 2018), and often difficult working conditions (e.g., lack of support for CLIL, problematic colleagues) (Codó \& Patiño-Santos, 2018; Gruber, 2017; Hofstadler, Talbot, Mercer, \& Lämmerer, 2018).

In the primary context, teacher wellbeing, job satisfaction and teacher burnout are only addressed in a very small number of studies despite the unique challenges that educators at the primary level face. Chaplain (2006), for instance, mentioned that English primary school teachers perceived a high level of stress and reported low job satisfaction due to, for instance, lack of teaching resources. In the Spanish primary setting, Betoret (2009) found stressors and reasons for burnout included lack of school support and low self- 


\section{${ }^{66}$ In the primary context, teacher wellbeing, job satisfaction and teacher burnout are only addressed in a very small number of studies despite the unique challenges that educators at the primary level face. 99}

efficacy related to classroom management and instruction. In Skaalvik and Skaalvik's (2009) study of Norwegian primary and secondary school teachers, they found that job satisfaction related directly to emotional exhaustion and reduced personal accomplishment stemming from aspects such as poor supervisory support, time pressure, difficult relations to parents and lack of autonomy. Our question is whether teaching CLIL at primary level adds any additional stressors to the experience or whether it may, in fact, act as a boost to teacher wellbeing in a new role.

\subsection{Primary CLIL in Austria}

In Austrian primary schools, teachers have a high level of autonomy as the curriculum provides only guidelines for the implementation of CLIL. What they teach, when and for how long can be decided upon by the individual school and teacher. It is within this context that the teachers are also meant to incorporate CLIL. However, primary school teachers are not trained specialists in foreign language learning; they are trained generalists in eight subjects (German, maths, science, music, physical education, wood and needle work, art and modern foreign languages). Within their per-service education, foreign language learning plays a minimum role ( 6 to 8 ECTS out of a 240 ECTS programme, where one ECTS stands for approximately 25-30 hours of work). The national curriculum guidelines stipulate that FL learning can be integrated into any general subject except German, reading and writing. In the majority of cases, class teachers also serve as CLIL teachers. However, these teachers' attitudes towards English have been described as "somewhat non-committal" (Dalton-Puffer, Faistauer, \& Vetter, 2011, p. 193), even though foreign language teaching has been a compulsory part of the Austrian primary school curriculum in years 3 and 4 since 1986, in KS I (key stage I) since 1998 and has been integrated into any of the general subjects since 2003 .

Given the pace at which CLIL is being extended across Austria, it is a matter of some urgency that teachers' perspectives and their psychological responses to working in CLIL settings are fully understood. Therefore, this study sought to address the following research questions:
RQ1:

What are the beliefs and motivations of primary CLIL teachers about their role as CLIL educators at primary level?

RQ2:

What contributes to primary CLIL teachers' professional subjective wellbeing?

RQ3:

What are the implications of the findings for classroom practice, pre-service and in-service teacher training and ongoing professional development and policy decisions?

\section{Research design and methodology}

7 his study is part of a larger project that investigates the wellbeing of CLIL teachers across primary, secondary and tertiary sectors based on in-depth semi-structured interviews and a nationwide survey ${ }^{1}$. In this paper, we focus in detail on the interview data collected from six CLIL primary school teachers with the intention to dig deep and gain rich insights into the experiences of the individuals and community group (O’Leary, 2010).

\subsection{Interviews}

The in-depth semi-structured interviews were conducted over a period of two months. They were designed using primarily open-ended questions, following predetermined themes across all participants. The interview protocol has been piloted with a primary teacher and CLIL primary teacher trainer, who provided feedback which led to some questions being adapted specifically for the primary context. Thematically, the interview protocol (see Appendix A) has been created by the general project team using open questions to explore several predefined themes while also allowing new phenomena to appear. It was structured into two main sections. Section one focused on the teachers' personal experiences and beliefs regarding CLIL. Section two explored their professional wellbeing, both in general and with regards specifically to their CLIL role. The relatively open structure of the interview protocol also provided enough space for participants to report on their professional experiences in a natural way that allowed for new phenomena to emerge and to encompass a more holistic perspective.

The interviews were conducted with six CLIL primary school teachers and each interview lasted for approximately $45 \mathrm{~min}$. The interviews, which were scheduled at the participants' convenience, were conducted by two members 


\begin{tabular}{|c|c|c|c|c|c|c|}
\hline & Sex & $\begin{array}{c}\text { Age } \\
\text { in years }\end{array}$ & $\begin{array}{l}\text { Teaching } \\
\text { experience } \\
\text { in years }\end{array}$ & $\begin{array}{c}\text { Teaching } \\
\text { experience } \\
\text { with CLIL }\end{array}$ & $\begin{array}{l}\text { Length } \\
\text { of interview }\end{array}$ & $\begin{array}{l}\text { Amount of CLIL } \\
\text { hours required } \\
\text { by school }\end{array}$ \\
\hline Interview I & female & 29 & 7 & 6 & $54 \mathrm{~min}$ & 5h/week \\
\hline Interview II & female & 28 & 9 & 8 & 1h $9 \min$ & $5 \mathrm{~h} /$ week \\
\hline Interview III & female & 29 & 7 & 7 & 1h $14 \mathrm{~min}$ & $5 \mathrm{~h} /$ week \\
\hline Interview IV & female & 27 & 5 & 4 & 1h $18 \mathrm{~min}$ & 3h/week \\
\hline Interview IV & female & 35 & 5 & 5 & $1 \mathrm{~h} 18 \mathrm{~min}$ & 3h/week \\
\hline Interview V & female & 38 & 7 & 7 & $1 \mathrm{~h} 2 \mathrm{~min}$ & 6h/week \\
\hline
\end{tabular}

Note: Two teachers participated in interview IV.

Table 1. Basic information about interviewees and interviews.

of the research team and took place between November 2017 and December 2017. All interviews were carried out in German and lasted between 54 minutes and one hour and 18 minutes. It is important to note that participants four and five (Interview IV) only agreed to participate in this study if they were interviewed together. Even though interviewing two volunteers at the same time might create the risk that one influences the other, the respondents seemed self-confident, direct and honest in their answers. There are also numerous incidents when they disagreed and countered each other's points.

The interviews generated 337 minutes of data (see Table 1). They were transcribed ready for content analysis, including relevant pauses, laughter, and silences. Grammatical errors and speech markers were not taken into consideration. This created a corpus of 30,130 words for analysis.

\subsection{Participants}

In total, six primary school teachers from three primary schools in the federal state of Styria volunteered to take part in the study. All participants were female and self-identified as CLIL teachers. Five out of six were class teachers. One teacher had a part-time commitment being employed solely as an English teacher. The age of the interviewees was rather homogenous, ranging from 27 years to 38 years. Accordingly, the participants' teaching experience ranged between four and eight years. All participants' first language was German.

It is important to note that, despite having contacted a large number of primary teachers across Austria, response rates were low and ultimately only achieved by drawing on personal connections. We reflect on possible reasons for the low levels of participation in section 5 (Discussion). Sadly, by the time the interviews took place, all the teachers had recently quit CLIL teaching as will be elucidated below.

\subsection{Ethics}

All Interviewees were contacted by the research team via e-mail. They were provided with information about the purpose of the study as well as a consent sheet, detailing the implications of their participation. All participants signed a consent form prior to the interview and gave their explicit permission to record, transcribe, and utilize their data for the study. Names, places, and other identifying information have been changed to ensure the participants' anonymity. As a small token of gratitude, all teachers received a box of chocolates.

\subsection{Data analysis}

The qualitative data was audio-recorded, transcribed and later coded with the help of QCAmap software (Mayring, 2013) in an inductive manner, which allowed themes to emerge but retained a focus on teacher psychology with respect to CLIL. The primary researcher went through the data line-by-line assigning codes (Bortz \& Döring, 2009; Brosius, Haas, \& Koschel, 2012). To ensure reliability and validity as well as to counteract misinterpretations, coding errors and the loss of content or data (Diekmann, 2013; Flick, 2012), the data analysis process was supported by inter-coder agreements, whereby the data sets were reviewed by two additional research group members (Creswell \& Miller, 2000), who were trained by the first coder. Overall, the data have undergone eight waves of coding, conducted by the entire research team, consisting of four researchers, as well as extensive memoing by one member of the research team. As interviews were conducted in German, raw data and codes had to be translated into English for the final report, which were validated by a bilingual research group member. Mindful of the limitations of such small samples, explanations and findings were built from the ground up by arranging categories around core themes of the collected data, which allowed researchers to identify specific patterns in relation to the primary teachers' wellbeing and CLIL. 


\section{Findings}

$\mathrm{T}$ he analysis revealed a number of factors, which the teachers perceived as promoting or threatening their wellbeing.

\subsection{Factors perceived as promoting wellbeing}

\section{Conviction about CLIL}

Generally, the beliefs participants held about CLIL were overwhelmingly positive as might be expected from a selfselected, volunteer population. All interviewees (I1, I2, I3, I4, I5, I6) expressed a positive interest in CLIL. Being able to teach following a personal conviction is likely to be positive for one's workplace wellbeing. Examples of some of the kinds of beliefs the teacher held include, for example, the conviction that CLIL is beneficial for pupils with respect to their language learning (I1, I2, I5, I6).

Two of the teachers (I1, I2) also expressed a belief that CLIL is a fun alternative to regular teaching practice for both students and teachers. Furthermore, interviewees 1 and 2 described CLIL as "something different", explaining that it "simply is fun and not like German, Maths or Science" (I1 B126) because it is "not always the same input, therefore, [the] children benefit from it" (I2_B59).

\section{Pupils and motivation}

One factor that appears to contribute to these CLIL teachers' wellbeing is their positive relationship and rapport with the pupils (cf. Gallagher, 2017). All interviewees identified a positive aspect of their job when they were doing "something with children, where they are full of enthusiasm and they are in it" (I6_B408). In fact, being part of their pupils' lives, seeing how they develop over the years and helping them improve were reported as the most motivating factors for all interviewees.

\section{Autonomy and environment}

All the teachers also reported feeling comfortable in their respective teaching environments, which includes good relationships to colleagues (I1, I4), and, of course, to their students (all), as well as their personalized classrooms (I4). It should be noted that class teachers in primary schools in Austria have their own classroom, which they keep for years and which they can decorate and personalize. In fact, for primary teachers, designing and personalizing the physical classroom space could possibly be an additional factor contributing to teachers' wellbeing.

\subsection{Challenges to wellbeing}

\section{Negative beliefs related to CLIL}

Across our data, it became apparent that there were only a few negative beliefs participants held about CLIL as an approach. Two individuals (I1, I2) criticised that they believed that CLIL might be less communicative than regular foreign language teaching, explaining that, "speaking is not always a priority" (I1_B24). For those teachers, CLIL has a focus on content learning rather than on language learning.

Three participants (I1, I2, I6) also believed that CLIL is more complicated to teach than regular English language teaching, as pupils might be more cognitively challenged in terms of following instructions and having to do more demanding tasks.

\section{Linguistic confidence}

Generally, language insecurity in the CLIL classroom was not an issue for the majority of participants (five of the six interviewees), who felt that they were "relatively secure in the language" (I2_B72) and described themselves as communicative and confident personalities (I1, I2, I3, I4, I5). However, two participants (I4, I6) reported having at some point experienced language insecurity in the CLIL classroom in that they questioned their own language skills, which they felt would "never match those of a native speaker" (I6_B381). Even though teacher 4 mentioned feeling rather secure in the foreign language by now, she reported having experienced insecurity at other points during her career. Interestingly, teacher 6 was the only participant who had received any kind of formalised specific English education. Yet, she explained that, "if you invest so much but still know that you will never reach the master level, you start to reconsider" (I6 B382) and stated that, ultimately, this unattainable goal and ideal of language proficiency was the reason for her to stop teaching CLIL altogether.

\section{Parents}

One factor that all the interviewees reported as being a stress factor negatively influencing their SWB is the pupils' parents. They all stated that they regularly had negative experiences with parents, from authority issues brought on by age or social hierarchy when parents "[...] come from a higher social class and [...] put you back in your place because you're just a teacher" (I3_B265) to not accepting the teacher and his/her decisions, leading in fact to a point which can make parentteacher interactions one of the most frustrating aspects of teaching, as the following quote illustrates: "Sometimes the parents' reactions are frustrating, who know very well how much one supports the children [...]. This critique, which sometimes comes off as almost hurtful, because I really try sure I am not faultless, who is? - but you can transport that with a certain appreciation [...] But blaming or in a certain 
tone, that is not appropriate, this is frustrating." (I2 B117)

Moreover, half of the interviewed teachers (I4, I5, I6) felt that parents added pressure specifically to their CLIL teaching in some way or other, including interference with lesson design as well as the need to justify the implementation of CLIL to parents.

One participant explained: "CLIL was denounced so many times [...] I had to explain myself so many times and had to justify all of it [...]" (I6_B396).

A particular issue frequently raised by parents is that some would prefer it if CLIL was taught by a 'native speaker'. As one teacher explained: "If you teach CLIL, then the parents' first question is, whether one is a native speaker [...] I did take time off, because we lived in Germany for a while and I did study English there for a year, primarily phonetics and still you never get close to a native speaker, and if you invest so much time and still, and it is not malicious of the parents, you have to cope with it, but the parents will always rub your nose in it, then it becomes unsatisfactory someday." (I6_B381)

None of these teachers were so-called 'native speakers', and, as such, this deficiency-view of their competences by parents appears to have a negative effect on their professional wellbeing.

\section{Workload}

With regards to workload, all of the teachers perceived it as being high. Comparing CLIL preparation to other subjects taught in their L1, most interviewees (I1, I2, I4, I5, I6) reported on generally needing more time due to the lack of suitable material for primary level CLIL, especially when teaching year 4 pupils. As teacher (I1) states, "[i]n year 4 to use CLIL on this level [...] to do English, is crazy, simply because it is massive in preparation, the arrangement, the preparation, the material, in year 4 [...] very exhausting [...]" (I1_B13). In fact, all the participants said that they create their own materials for the subjects they teach in English, which, in addition to general preparation aspects, also entails language-related challenges, such as finding subject-specific vocabulary and developing confidence in the foreign language.

Generally, not just in regard to CLIL, demands from various other job-related tasks such as bureaucracy, documentation, ad-hoc instruction allocated by the principal and local educational authority demands, were cited as posing challenges for their wellbeing for five of the teachers (I1, I2, I3, I4, I5). This extra time commitment adds additional pressure to an already demanding job.

\section{Lack of appreciation}

With regards to CLIL specifically, most Interviewees (I1, I2, I4, I5, I6) said that the amount of preparation needed for CLIL lessons was typically overlooked by authorities and not appreciated by head teachers or colleagues as being work more than usual. As described by participant 2, school administrators routinely failed to acknowledge teachers' efforts, especially with regards to CLIL, stating that she is "never told 'it's really great that you're doing this"' (I2_B32).

These instances were not only reported as hurtful but are also at odds with teachers' realities. While all interviewees explicitly stated that they liked their job, all of them described it as exhausting, both physically and mentally, explaining that, "school accompanies me day and night, holidays and weekends" (I3 B262). In fact, four of the interviewees (I1, I2, I3, I4) even stated that they viewed the conditions of their profession as poor, which was pointedly summarized by one of the teachers: "[...] You cannot even go to the toilet or drink or eat something, because you already prepare or clean up" (I3_B207).

\section{Perceived pressure of the transition to secondary school}

Another negative influence on these CLIL primary teachers' SWB was the perceived pressure and the fear of not being able to provide adequate input to ensure that students profited sufficiently to cope with the upcoming transition to secondary school. Particularly in year 4 , which is the final year at primary education before the pupils transition to a new secondary school, parents seem to care "solely about the grades in Maths and German" (I1_B183) as pupils need to have certain grades in order to be able to enter particular schools. Four out of six interviewees (I3, I4, I5, I6) stated that they experienced self-doubt over whether they had sufficiently prepared their pupils, in the light of forthcoming secondary education.

\section{Lack of organisation and support}

Another issue that was raised in the interviews was the lack of structure or CLIL guidelines. This left three of the interviewed teachers (I2, I4, I5) feeling quite alone with not only the implementation of the method itself but also the difficult task of fitting CLIL into an already packed existing schedule. As one teacher explained, "[...] there is still not enough room for English. A lot happens in German and in the topics, but you have to question how English can occur there, and this is always a bit uncomfortable" (I4/5 B336).

Even though CLIL was well-established in all of the schools at the time the interviews were conducted, all the interviewees (I1, I2, I3, I4, I5, I6) reported that they had given up teaching CLIL for various reasons. While three of the six teachers (I3, I4, I6) described their own personal reasons for reducing CLIL input, such as the overall lack of time (I3, I4) for English or the pressure to live up to impossible perceived language expectations (I6) such as having a native-like proficiency in the foreign language, which one participant reported as "[putting] so much pressure on me overall that it did not work for me anymore." (I6_B404), four participants (I1, I2, I4, 
I5) stated that CLIL had somewhat been sidelined by their administration in favour of other pedagogical priorities such as progressive pedagogical concepts (Montessori and Jenaplan).

The fact that schools and teachers are left alone without support in the initiation phase and there was reportedly no in-service training offered (I2, I4, I5) might be reasons that, despite these teachers' overall positive attitude towards CLIL, all the negative aspects together outweighed and failed to provide enough motivation for our interviewed teachers to continue their CLIL teaching in its intended format. As such, despite their strong convictions about the value of CLIL at primary level and pleasure in teaching it, all of the teachers in this study had stopped using CLIL.

\section{Discussion}

A 11 three schools implemented CLIL according to Austria's curricular requirements; however, due to a lack of unified, specific guidelines, all the teachers reported implementing CLIL to a different amount each week and with different views about what CLIL actually comprised. Even though CLIL's flexibility allows practitioners to decide for themselves how to realise and integrate it into classrooms, it might also water down its intended characteristics (Wimmer, 2009) and confuse teachers about their responsibilities and specific teaching aims (Coyle et al., 2010; European Commission, 2003). This diversity had a paradoxical effect in our study. In one respect, the teachers appreciated the autonomy and absence of formalised pressure, but, on the other hand, they felt a lack of support and clarity about whether learners were reaching the right kind of levels and whether they as teachers were really doing what was expected of them (cf. Hofstadler et al., 2018).

Key factors affecting the teachers' wellbeing positively were their perceived enhanced relationship with their pupils and their own positive attitudes towards and conviction about the benefits of CLIL. This finding is in line with other research on teachers generally which shows how important rapport is for teacher motivation (Dörnyei \& Csizér, 1998) and how satisfying it is to teach in line with one's pedagogical beliefs (Farrell, \& Ives, 2015). In the primary setting, these teachers mentioned that CLIL teaching is somehow different and allows them to take a 'special role' in which teaching in English is fun and different to the format of regular classes. If teachers enjoy teaching, not only is it good for their wellbeing (Day \& Qing, 2009; Duckworth, Quinn, \& Seligman, 2009), but it is also beneficial for their learners who are also likely to enjoy the classes more (Roffey, 2012) setting off a reciprocal cycle of positivity for both teachers and learners.

However, despite finding many aspects of CLIL work in primary school positive, these teachers ultimately struggled with several challenges which meant that all of the teachers ultimately gave up teaching CLIL altogether. A key negative impact factor was the work with parents related to CLIL and feeling the need to have to justify CLIL to them. Parents demanding a CLIL teacher to be a native speaker can have potentially detrimental effects on teachers' sense of efficacy and professional identity (Gruber, 2017); particularly in schools that offer CLIL based on parents high value (mainly private ones), where they at the same time expect their children to reach a certain standard by the end of year 4 . Gruber (2017) also found a belief among parents that "native speakers are indispensable" (p. 228); however, parents do not seem to be aware that even though native speakers can bring a cultural component to the school, not every native speaker has the ability to teach CLIL or any other specific competences (including knowledge of the CLIL concept, subject competences, language competences or pedagogical training for target age group) to deliver lessons adequately (Ball et al., 2015; Bruton, 2011). It suggests that one action schools need to take is to inform parents about the nature of CLIL and seek to dispel the myths surrounding the notions of native speaker teachers.

The perceived lack of appreciation for teaching from mainstream society and the teachers' own environment (see 4.2.4.) seemed to be another challenge to these teachers' wellbeing. Hofstadler et al. (2018) found that a "lack of insight and understanding about teachers' lives and responsibilities was a cause of frustration" (p. 11). Indeed, various studies have shown that, in fact, teaching is one of the most stressful careers (Kieschke \& Schaarschmidt, 2008; Kyriacou, 2001) and yet it appears to receive low status in some contexts (Andrews, 2011), including the setting of this study.

\section{${ }^{66}$ If teachers enjoy} teaching, not only is it good for their wellbeing (Day \& Qing, 2009; Duckworth, Quinn, \& Seligman, 2009), but it is also beneficial for their learners who are also likely to enjoy the classes more (Roffey, 2012) setting off a reciprocal cycle of positivity for both teachers and learners.' 
Ultimately, these teachers have all abandoned their CLIL teaching, seemingly "as a defense mechanism against the unusually high level of stress inherent to their work" (Hiver \& Dörnyei, 2015, p. 2). What is more surprising is that this has happened despite the fact that three of these teachers reported having a good work-life balance. It is likely that these teachers became more experienced and confident over the years (Pappa et al., 2017; Vähäsantanen, 2015) in coping with uncomfortable situations, but also in lesson preparation and keeping a healthy distance from school topics, pupils and parents. Nevertheless, Hiver and Dörnyei (2015) postulate that this form of teacher immunity (i.e., "a defense mechanism against the material and emotional demands which are part of their practice" (Hiver, 2016, p. 6)) might not only function constructively, but could also be used defensively and ultimately inhibit growth and change. It is possible that these teachers resisted further CLIL teaching concluding that the effort and investment it required was not worth the output with learners or parents or indeed with their principals or society more broadly. A simple costbenefit calculation on their part could mean that the lack of appreciation balanced against the amount of time and energy needed, simply was not worth it in the end.

While this study has offered rich, nuanced insights into the wellbeing of these CLIL teachers in the primary sector, there are also limitations. Naturally, the sample is small and the context is limited as all of these teachers worked in the same region of Austria. It would be invaluable to expand the study with a wider spectrum of teachers, of different gender, age, years of experience and countries of work. Additionally, all the participants volunteered and so this is likely to skew the responses, although it is telling that despite their overall positive attitudes towards CLIL, they were ultimately withdrawing in face of the challenges they were encountering of CLIL in practice at the primary level. Interestingly, it is exactly those teachers who are struggling to cope with the time pressures and role responsibilities that research needs to comprehend and, yet, understandably, those are the ones least likely to volunteer for interviews. For us generally, it was extremely difficult to find CLIL teachers with the time who were willing to participate. Indeed, this remains a problem challenging researchers wanting to work with teachers generally across the career trajectory (Mercer \& Kostoulas, 2018). Yet, understanding practising, in-service teachers and their lived experiences is vital to ensuring all teachers across the career lifespan receive the support they need to flourish in their professional roles.

\section{Conclusion}

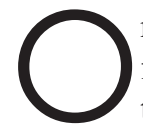
$\mathrm{n}$ the whole, this study has revealed a number of factors, which appear to support these CLIL primary teachers' wellbeing and those that challenge it. It was noted that some of these factors are issues for all teachers generally and others were specific to teaching CLIL at this level. We also found relative homogeneity within the participant sample but this can be a result of the similar profile of the participants.
The study has a number of implications for interventions and training programmes. Firstly, regardless of the number of years they had been teaching, the respondents were not fully confident about how to interpret CLIL due to a perceived lack of guidelines and training. Due to Austrian primary school teachers' autonomy to decide on the content, themes and length of instruction, CLIL varies widely in school and region (Dalton-Puffer, 2007; Eurydice, 2006). Hence, it seems important to clarify and define CLIL at the primary school level with the teachers, so that misunderstandings are minimised and teachers have clear expectations and sense of direction. In addition, it suggests the benefits of training courses to teach approaches but also provide materials and develop a network for exchange of ideas between teachers. Further, the pressures from society more broadly and parents specifically imply that teachers need more support from their institutions and principals. Better information and public relations could also make clear more broadly just what an incredibly valuable contribution teachers make to children's growth and thus to society more widely, and how demanding their jobs are on a day-to-day basis.

Teachers, who are healthy and happy, are the most effective and creative teachers and their learners typically have higher levels of achievement (Hiver \& Dörnyei, 2015; Sheldon, Cheng, \& Hilpert, 2011). This means that ensuring that teachers are happy in their professional roles and enjoying high levels of wellbeing is not an additional luxury but a core foundation of good teaching practice. Especially in a CLIL context, teachers may perceive additional stressors, such as linguistic insecurity, parents' expectations, additional work load as well as a lack of appreciation, support and organisation, which are important to understand, to ensure these teachers receive the support they need to be the best CLIL educators they can possibly be without this being at the cost of their professional wellbeing.

\section{Acknowledgment}

This research would not have been possible without a generous grant from the Austrian National Bank (ÖNB) (The Subjective Well-Being of CLIL Teachers in Austria, 17136). The authors would also like to thank the CLIL teachers for their kind participation, Diana Millonig for helpful information at an early stage of the project and the anonymous reviewers for their feedback.

\section{Notes}

1 The general project employed a multi-method design combining in-depth, semi-structured interviews with 36 teachers from a range of CLIL educational contexts and a survey. The survey utilised the CLIL Teachers' WellBeing Questionnaire (CLILTWB) based on insights stemming from the interviews alongside an occupational well-being questionnaire based on the PERMA Profiler and the Satisfaction with Life Scale (SWLS). 


\section{References}

Aelterman, A., Engels, N., Van Petegem, K.,\& Verhaeghe, J. P. (2007). The well-being of teachers in Flanders: the importance of a supportive school culture, Educational Studies, 33(3), 285-297.

https://doi.org: 10.1080/03055690701423085

Aguilar, M., \& Rodríguez, R. (2012). Lecturer and student perceptions on CLIL at a Spanish university. International Journal of Bilingual Education and Bilingualism, 15(2), 183-197.

https://doi.org/10.1080/13670050.2011.615906

Alarcao, I., Andrade, A., Araújo, M., Melo-Pfeifer, S., \& Santos, L. (2009). Intercompréhension et plurilinguisme: (re)configurateurs épistemologiques d'une didactique des langues? Etudes de Linguistique Appliquee: Revue de Didactologie des Langues-cultures et de Lexiculturologie, 153, 11-24.

https://doi.org/10.3917/ela.153.0011

Andrews, H. A. (2011). Supporting Quality Teaching with Recognition. Australian Journal of Teacher Education, 36(12).

http://dx.doi.org/10.14221/ajte.2011v36n12.5

Ball P., Kelly, K., \& Clegg, J. (2015). Putting CLIL into Practice. Oxford: Oxford University Press.

Barber, M., \& Mourshed, M. (2007). How the world's bestperforming school systems come out on top. McKinsey \& Company.

Beauchamp, C.,\& Thomas, L. (2009). Understanding teacher identity: An overview of issues in the literature and implications for teacher education. Cambridge Journal of Education, 39(2), 175-89.

https://doi.org/10.1080/03057640902902252

Betoret, F. D. (2009). Self-efficacy, school resources, job stressors and burnout among Spanish primary and secondary school teachers: a structural equation approach, Educational Psychology, 29(1), 45-68.

https://doi.org: 10.1080/01443410802459234

Borman, G. D.,\& Dowling, M. (2008). Teacher Attrition and Retention: A Meta-Analytic and Narrative Review of the Research. Review of Educational Research 78(3). 367409.

https://doi.org: 10.3102/0034654308321455

Bortz, J.,\& Döring, N. (2009). Forschungsmethoden und Evaluation für Human- und Sozialwissenschaftler $\left(4^{\text {th }}\right.$ ed.). Heidelberg: Springer Medizin Verlag.
Bovellan, E. (2014). Teachers' Beliefs About Learning Content and Language Integrated Learning (CLIL). (Doctoral dissertation). University of Jyväskylä, Jyväskylä, Finland. Retrieved from https://pdfs. semanticscholar.org/f567/5223212fe0ebcc0391adcc89b fff307e17e8.pdf

Briner, B.,\& Drewberry, C. (2007). Staff wellbeing is key to school success. A research study into the links between staff wellbeing and school performance. Worklife Support Ltd. Retrieved from www.worklifesupport.com.

Brosius, H.-B., Haas, A., \& Koschel, F. (2012). Methoden der empirischen Kommunikationsforschung. Eine Einführung. Wiesbaden: Springer VS.

https://doi.org/10.1007/978-3-531-94214-8

Bruton, A. (2011). Is CLIL so beneficial, or just selective? Re-evaluating some of the research. System, 39(4), 523532.

https://doi.org/10.1016/j.system.2011.08.002

Buchholz, B. (2007). Facts \& Figures im GrundschulEnglisch. Eine Untersuchung des verbindlichen Fremdsprachenunterrichts ab der ersten Klasse an österreichischen Volksschulen. Wien: Lit Verlag GmbH \& Co. KG.

Bundesministerium für Unterricht, Kunst und Kultur (BMUKK; nunmehr Bundesministerium für Bildung und Frauen [BMBF]). (2012). Lehrplan der Volksschule. BGB1. Nr. 134/1963 in der Fassung BGB1. II Nr. 303/2012 vom 13. September 2012. Retrieved from https://www. bmbf.gv.at/schulen/unterricht/lp/lp_vs_gesamt_14055. $p d f$

https://doi.org/10.1524/9783050085036.118

Burmeister, P., \& Pastemak, R. (2007). Exciting and dangerous...Das Thema "Fire" im fremdsprachlichen Sachfachunterricht. Grundschule. 39(4), 36-40.

Byrne, B. M. (1999). The nomological network of teacher burnout: A literature review and empirically validated model. In R. Vandenberghe,\& A. M. Huberman (Eds.), Understanding and preventing teacher burnout: A sourcebook of international research and practice (pp. 15-37). New York, NY, US: Cambridge University Press. https://doi.org/10.1017/cbo9780511527784.003

Caprara, G. V., Barbaranelli, C., Steca, P., \& Malone, P. S. (2006). Teachers' self-efficacy beliefs as determinants of job satisfaction and students' academic achievement: A study at the school level. Journal of School Psychology, 44(6), 473-490.

https://doi.org/10.1016/j.jsp.2006.09.001 
Chaplain, R. P. (1995). Stress and Job Satisfaction: a study of English primary school teachers, Educational Psychology, 15(4), 473-489.

https://doi.org:10.1080/0144341950150409

Clear, J. (2005). The problems a German higher education institution faces when offering courses conducted in English. In M. Motz (Ed.). Englisch oder Deutsch in internationalen Studiengängen? (pp. 193-202). Frankfurt am Main: Peter Lang.

Codó, E., \& Patiño-Santos, A. (2018). CLIL, unequal working conditions and neoliberal subjectivities in a state secondary school. Language Policy, 17(4), 479-499.

https://doi.org/10.1007/s10993-017-9451-5

COM: European Commission. (2009). Early language learning in Europe. Facts \& figures and FAQs. Memo/09/415. Brussels: European Commission. Retrieved from http://europa.eu/rapid/press- release MEMO-09-415_en.htm?locale=en (2014, Oct. 22).

Coonan, C. M. (2007). Insider views of the CLIL class through teacher self-observation-introspection. International Journal of Bilingual Education and Bilingualism, 10(5), 625-646.

https://doi.org/10.2167/beb463.0

Coyle, D., Hood, P., \& Marsh, D. (2010). CLIL: Content and language integrated learning. Cambridge: Cambridge University Press.

Creswell, W. J., \& Miller, D. L. (2000). Determining validity in qualitative inquiry. Theory into Practice, 39(3), 124130.

https://doi.org/10.1207/s15430421tip3903_2

Dafouz, E., \& Guerrini, M. C. (Eds.). (2012). CLIL across educational levels: Experiences from primary, secondary and tertiary contexts. Madrid: Richmond Publishing.

Dalton-Puffer, C. (2007). Discourse in Content and Language Integrated Learning (CLIL) classrooms. Amsterdam: John Benjamins Publishing Company.

https://doi.org/10.1515/iprg.2009.021

Dalton-Puffer, C., \& Smit, U. (Eds.). (2007). Empirical perspectives on CLIL classroom discourse. Frankfurt: Peter Lang.

https://doi.org/10.3726/978-3-653-01829-5

Dalton-Puffer, C., Faistauer, R., \& Vetter, E. (2011). Research on language teaching and learning in Austria (2004-2009). Language Teaching, 44, 181-211.

https://doi.org/10.1017/s0261444810000418
Day, C., \& Qing, G. (2009). Teacher emotions: Wellbeing and effectiveness. Advances in teacher emotion research. Boston: Springer, 15-31.

https://doi.org/10.1007/978-1-4419-0564-2_2

Diekmann, A. (2013). Empirische Sozialforschung. Grundlagen, Methoden, Anwendung. Reinbek bei Hamburg: Rowohlt Verlag.

Diener, E. (1984). Subjective well-being. Psychological bulletin, 95(3), 542-575.

https://doi.org/10.1037//0033-2909.95.3.542

Diener, E., Heintzelman, S. J., Kushlev, K., Tay, L., Wirtz, D., Lutes, L. D., \& Oishi, S. (2017). Findings all psychologists should know from the new science on subjective well-being. Canadian Psychology/psychologie canadienne, 58(2), 87-104.

https://doi.org/10.1037/cap0000063

Diener, E., Lucas, R. E., \& Oishi, S. (2002). Subjective Wellbeing: The Science of Happiness and Life Satisfaction. In C.R. Synder,\& S. J. Lopez (Eds.), Handbook of Positive Psychology (pp. 63-73). Oxford: Oxford University Press.

https://doi.org/10.1093/oxfordhb/9780195187243.013.0017

Dörnyei, Z., \& Csizér, K. (1998). Ten commandments for motivating language learners: Results of an empirical study. Language teaching research, 2(3), 203-229. https://doi.org/10.1191/136216898668159830

Duckworth, A. L., Quinn, P. D., \& Seligman, M. E. (2009). Positive predictors of teacher effectiveness. The Journal of Positive Psychology, 4(6), 540-547.

https://doi.org/10.1080/17439760903157232

European Commission. (2003). Promoting language learning and linguistic diversity: An action plan 2004-2006, 1-29. Retrieved from http://ec.europa.eu/education/doc/ official/keydoc/actlang/act_lang_en.pdf

European Parliament. (2001). The 2001 charter of fundamental rights of the European Union.

Eurydice. (2006). Content and language integrated learning at school in Europe. Retrieved from http://eacea. ec.europa.eu/education/eurydice/thematic_studies_ archives_en.php

Farrell, T. S. C. (2016). Surviving the transition shock in the first year of teaching through reflective practice. System, 61, 12-19.

https://doi.org/10.1016/j.system.2016.07.005 
Farrell, T. S., \& Ives, J. (2015). Exploring teacher beliefs and classroom practices through reflective practice: A case study. Language Teaching Research, 19(5), 594-610.

https://doi.org/10.1177/1362168814541722

Flick, U. (2012). Qualitative Sozialforschung: Eine Einführung. Reinbek bei Hamburg: Rohwolt Verlag.

Gallagher, M. (2017). Exploring Resilience and Wellbeing with Mid-career Primary Teachers in Aotearoa/New Zealand: A Strengths-Based Approach. (Master thesis). University of Otago, Dunedin, New Zealand.

https://doi.org/10.26473/atlaanz.2015.1.1/001

Gierlinger, E. (2007). Modular CLIL in lower secondary education: some insights from a research project in Austria. In C. Dalton-Puffer,\& U. Smit (Eds.), Empirical Perspectives on CLIL Classroom Discourse (pp. 79118). Frankfurt am Main: Peter Lang.

https://doi.org/10.3726/978-3-653-01829-5/5

Gruber, M.-T. (2017). PrimA-CLIL: Multiple Stakeholders' Perceptions of CLIL and its Implementation at the Primary School Level in Austria. (Doctoral dissertation). University of Graz, Graz, Austria.

Hiver, P. (2016). Tracing the signature dynamics of language teacher immunity (Doctoral dissertation). University of Nottingham, Nottingham, UK. Retrieved from http:// eprints.nottingham.ac.uk/33626/

Hiver, P. \& Dörnyei, Z. (2015). Language Teacher Immunity: A Double-Edged Sword. Applied Linguistics, 1-20. https://doi.org:10.1093/applin/amv034

Hofstadler, N., Talbot, K., Mercer, S. J.,\& Lämmerer, A. (2018). The Thrills and Ills of CLIL. In Gkonou, C., Dewaele J. M.,\& King J. (Eds.), Language Teaching: An emotional Rollercoaster (in press). Clevedon: Multilingual Matters.

Infante, D., Benvenuto, G., \& Lastrucci, E. (2008). Integrating content and language at primary school in Italy: Ongoing experimental research. International CLIL Research Journal, 1(1), 74-82. Retrieved from http://www.icrj.eu/11/article6.html

Johnson, B., Down, B., Le Cornu, R., Peters, J., Sullivan, A., Pearce, J., \& Hunter, J. (2016). Promoting early career teacher resilience: A socio-cultural and critical guide to action. London: Routledge.

https://doi.org/10.4324/9781315745602

Kieschke, U., \& Schaarschmidt, U. (2008) Professional commitment and health among teachers in Germany: A typological approach. Learning and Instruction 18(5),
429-437.

https://doi.org/10.1016/j.learninstruc.2008.06.005

Kokkinos, C. M. (2007). Job stressors, personality and burnout in primary school teachers. British Journal of Educational Psychology, 77(1), 229-243.

https://doi.org:10.1348/000709905X90344.

Krey, K. (2009). Content and language integrated learning (CLIL). An introduction to didactics and methodology. Retrieved from http://www.seminar-tuebingen.de/ site/pbs-bw/get/documents/KULTUS.Dachmandant/ KULTUS/Seminare/seminar-tuebingen-gym/pdf/ TueSem_EuroConMi_Kr.pdf

Kyriacou, C. (2001) Teacher stress: Directions for future research. Educational Review 53(1), 27-35.

Larsen, R. J., \& Prizmic, Z. (2008) Regulation of emotional well-being: Overcoming the hedonic treadmill. In M. Eid,\&R. J. Larsen (Eds.), The Science of Subjective Wellbeing (pp. 258-289). New York: Guilford Press.

Lovewell, K. (2012). Every Teacher Matters: Inspiring Wellbeing through Mindfulness. St. Albans: Ecademy Press.

Marsh, D., Järvinen, H.-M., \& Haataja, K. (2007). Finland: Perspectives from Finland. In A. Maljers, D. Marsh,\& D. Wolff (Eds.),Windows on CLIL: Content and language integrated learning in the European spotlight (pp.63-83). The Hague: European Platform for Dutch Education.

Maslach, C., Schaufeli, W. B., \& Leiter, M. P. (2001). Job Burnout. Annual Review of Psychology 52(1), 397-422. https://doi.org:10.1146/annurev.psych.52.1.397

Massler, U. (2012). Primary CLIL and its stakeholders: What children, parents and teachers think of the potential merits and pitfalls of CLIL modules in primary teaching. International CLIL Research Journal, 1(4), 36-46. Retrieved from http://www.icrj.eu/14/article4.html

Mayring, P. (2013). QCAmap: A software for qualitative content analysis. Retrieved from $h t t p: / / w w w . q c a m a p . o r g$

Mehisto, P., Marsh, D., \& Frigols, M. J. (2008). Uncovering CLIL. Between Towns Road, Oxford: Macmillan Publisher Limited.

Mercer S.,\& Kostoulas, A. (2018). Introduction to language teacher psychology. In S. Mercer,\& A. Kostoulas (Eds.), Language Teacher Psychology (pp. 1-17). Bristol, UK: Multilingual Matters.

https://doi.org/10.21832/9781783099467-005

Millonig, D. J. (2015). Integrating English as a 
Foreign Language in Austrian primary schools: contextual and participant perspectives (Doctoral dissertation). The Open University,Milton Keynes, UK. Retrieved from https://pdfs.semanticscholar.or g/09f5/88147dfa476e1cc1494e984320f590ee8687. $p d f ? \_g a=2.234489566 .1525648438 .1573396081$ 1545921658.1569618835

Moate, J. (2014). "A Narrative Account of a Teacher Community." Teacher Development 18(3), 384-402. https://doi.org:10.1080/13664530.2014.931294

O'Leary, Z. (2010). The essential guide to doing your research project. London: Sage Publications Ltd.

Pappa, S., Moate, J., Ruohotie-Lyhty, M.,\& Eteläpelto, A. (2017). Teachers' pedagogical and relational identity negotiation in the Finnish CLIL context. Teaching and Teacher Education, 65, 61-70.

https://doi.org/10.1016/j.tate.2017.03.008

Pavot, W., Diener, E., Oishi, S., \& Tay, L. (2018). The cornerstone of research on subjective well-being: Valid assessment methodology. Handbook of Well-Being. Noba Scholar Handbook Series: Subjective Well-Being. Salt Lake City, UT: DEF Publishers.

https://doi.org/10.1007/978-90-481-2352-0_5

Pladevall-Ballester, E. (2018). A longitudinal study of primary school EFL learning motivation in CLIL and non-CLIL settings. Language Teaching Research, 1-22. https://doi.org/10.1177/1362168818765877

Read, C. (2005). Is young better? English Teaching Professional, 28, 5-7.

Rixon, S. (2001). Young learners of English: Some research perspectives. London: Longman.

Rixon, S. (2013). British Council survey of policy and practice in primary English language teaching worldwide. London: The British Council.

Roffey, S. (2012). Pupil wellbeing - teacher wellbeing: Two sides of the same coin? Educational and Child Psychology, 29(4), 8-17.

Sheldon, K. M., Cheng, C., \& Hilpert, J. (2011). Understanding Well-Being and Optimal Functioning: Applying the Multilevel Personality in Context (MPIC) Model, Psychological Inquiry. An International Journal for the Advancement of Psychological Theory, 22(1), 1-16.

https://doi.org/10.1080/1047840x.2011.532477

Singleton, D. (2002). The age factor in second language acquisition ( $2^{\text {nd }}$ ed.). Clevedon: Multilingual Matters.

Singleton, D. (2003). Critical Period or General Age Factor(s)? In M. Garcia Mayo,\& M. Garcia Lecumberri (Eds.), Age and Acquisition of English as a foreign language (pp. 3-23). Clevedon: Multilingual Matters. https://doi.org/10.21832/9781853596407-002

Skaalvik, E. M., \& Skaalvik, S. (2006). Does school context matter? Relations with teacher burnout and job satisfaction. Teaching and Teacher Education, 25(4), 518-524.

https://doi.org:10.1016/j.tate.2008.12.006

Sudhoff, J. (2010). CLIL and intercultural communicative competence: Foundations and approaches towards a fusion. International CLIL Research Journal, 1(3), 3037.

Talbot, K., \& Mercer, S. (2018). Exploring University ESL/ EFL Teachers' Emotional Well-Being and Emotional Regulation in the United States, Japan and Austria. Chinese Journal of Applied Linguistics, 41(4), 410-432. https://doi.org/10.1515/cjal-2018-0031

Vähäsantanen, K. (2015). Professional agency in the stream of change: Understanding educational change and teacher's professional identities. Teaching and Teacher Education, 47, 1-12.

https://doi.org/10.1016/j.tate.2014.11.006

Vázquez, V. P., \& Ellison, M. (2018). Examining teacher roles and competences in Content and Language Integrated Learning (CLIL). Linguarum Arena:Revista de Estudos em Didática de Línguas da Universidade do Porto, 4, 6578.

Vázquez, V. P., \& Gaustad, M. (2013). Designing bilingual programmes for higher education in Spain: Organisational, curricular and methodological decisions. International CLIL Research Journal, 2(1), 82-94. Retrieved from http://www.icrj.eu/21/article7.html

Wimmer, R. (2009). A closer look at CLIL. English Teaching Professional, 64, 4-6. 


\section{Appendix}

INTERVIEW PROTOCOL

KARL-FRANZENS-UNIVERSITÄT GRAZ UNIVERSITY OF GRAZ

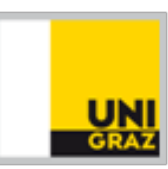

\author{
$\ominus N B$ \\ OESTERREICHISCHE NATIONALBANK \\ EUROSYSTEM
}

\section{BACKGROUND}

\section{Can you describe your journey to teaching in English?}

- Since when have you been teaching in English?

- How long have you been teaching in English? Do you teach in English every year?

- Did you choose to teach in English in your lessons or were you asked/forced to do so?

- Did you get any preparation for your English classes from the school or local authorities?

- What support did your school offer you for the lessons you teach in English?

- Do you feel that teaching in English influenced your development as a teacher in any way?

- Has your teaching (generally and in respect to teaching in English) changed? If so, how?

- How do you feel about teaching in English?

- What do you enjoy about teaching in English?

- What aspects do you find challenging about teaching English in elementary school?

- When you teach in English, do you also teach elements of the curriculum in English?

- Do you prefer teaching English as a language class or through other content? Why?

- What advice would you give to elementary school teachers who want to start teaching in English at their school?

\section{CLIL - APPROACHES AND IMPLEMENTATION}

\section{How do you feel about teaching in English in elementary school generally?}

- How do you see English in elementary school from the learner/teacher/school parent perspectives?

- What do you feel are the assumptions about language learning when it comes to teaching in English in elementary school lessons?

- Do you think all students profit from being taught in English? Why or why not?

- Do you think teaching in English is suitable for all teachers? Why or why not?

- Do you feel that teaching in English in elementary school is improving language education in Austria? Why or why not?

- Do you feel that teaching lessons in English is improving content education in Austrian elementary schools? Why or why not? 
- Do you think there are certain conditions under which teaching content/parts of the curriculum in English works better than others? If so, what would they be?

- How do you feel learners learn a language best?

- What advice would you give to new elementary school teachers?

\section{How is teaching in English implemented at your school?}

- Are there guidelines for teaching in English at your school? If so, what are they?

- If there are guidelines at your school, do you find them helpful? Why or why not?

- Do you prefer set guidelines from both a national and school level or not? Can you explain your answer?

- If you were in charge or making policy at the national/school level, what would you change if anything? What would you keep the same?

\section{How does teaching in English function at your school?}

- When do you start teaching in English, in which years?

- How many hours per week are assigned for English in each school year?

- How long are the sequences you teach in English?

- Do you use German in these English lesson? If so, when and why?

- Do you think teaching in English varies greatly among teachers at your school? Can you explain your answer?

- Do teachers get to volunteer to teach in English or are they forced to do it?

- Are there any training opportunities or qualifications offered for teachers at your school? Is so, can you describe them and how you feel about them?

- Would you say that you are satisfied with the way the teaching in English is run at your school?

- Do teachers collaborate at your school when it comes to teaching in English?

- Do you feel supported by the administration/head teacher?

- Do you feel confident contributing to discussions about teaching in English with the administration?

- Are there any incentives for teaching in English?

- How do other teachers feel about teaching in English in their classes?

- How do pupils feel? And how do you know or why?

- How do parents feel? And how do you know or why?

- In your opinion, what type of characteristics, qualities, or strengths would an effective teacher possess?

- Do those characteristics/qualities/strengths change when speaking about teaching in English in elementary school?

- What issues concerning the English lessons come up amongst teachers when you talk together? 


\section{CLIL - GUIDELINES, APPROACHES \& MATERIALS}

\section{Are there any guidelines regarding the material used for the lessons you teach in English at your school?}

- Can you describe the materials that you use for teaching in English?

- Are there any issues in their use?

- Do you have easy access to materials or do you usually make your own?

- If you do make your own materials, how do you feel about this?

- Does the school provide material for you or is it your own designs?

- If you use existent materials, are they designed for an Austrian context? How do you find the materials - strengths and drawbacks?

- What would you wish for in regards to materials for teaching lessons in English?

\section{You as a CLIL teacher}

- How confident do you feel when you teach in English?

- Do you have goals in your English classes that you are actively pursuing?

- Have you ever had any problems while teaching in English? How did you solve them?

- What have been the high points of teaching in English?

- If you had the choice, would you change anything?

\section{WELL-BEING \& WORK LIFE BALANCE}

\section{How confident do you feel in your abilities as a teacher generally, and specifically as a CLIL teacher?}

- What are your strengths as a teacher?

- How have these strengths helped you with?

- What areas would you like to work on in your professional repertoire?

- How does teaching in English relate to your other teaching?

- Has teaching in English generally enriched your professional life or weakened it? Can you explain why?

- Do you find teaching generally and teaching in English stressful?

- What aspects of your professional role cause you stress?

- How do you manage your stress?

\section{How would you describe your work-life balance?}

- Are you able to easily transition from teacher-mode to your personal life?

- Can you describe your ideal work-life balance?

- Has teaching in English affected your work-life balance in any way? 
- Do you feel you need to make any changes to your work-life balance?

\section{How integral do you see work satisfaction to overall life satisfaction?}

- How satisfied are you with being a teacher at the moment?

- How does your satisfaction at work affect your life out of work?

- What do you do to relax?

- What do you find rewarding about being a teacher?

- What are you looking forward to in coming years in your work role?

- Can you describe how you feel at work generally?

\section{What motivates you in respect to your teaching career?}

- What do you find especially motivating in your job? Are there aspects of your work that you find demotivating?

- When teaching in English, what moments or experiences make you feel joy or happiness?

- Is there a relationship that gives you strength - generally or in regard to school?

- How do your family feel about your job? Would you say they are supportive? If so, in what ways?

- Are there any aspects of your job as a teacher that you find especially meaningful?

- All things considered, would you say that you are satisfied with your work in general?

- What gives you happiness in respect your job/life generally?

- What, if anything, frustrates you about your job?

- What in your job are you most proud of?

- What are the tasks/aspects of your job you love doing the most?

- All things considered, how satisfied are you with your career generally these days?

\section{OTHER INFO}

11. Is there any info that you would like to add to our discussion?

- Do you have any questions for us? 